\title{
Use of complementary and alternative medicine in patients with health complaints attributed to former dental amalgam fillings
}

Agnete E. Kristoffersen ${ }^{1 *}$, Frauke Musial ${ }^{1}$, Harald J. Hamre ${ }^{2}$, Lars Björkman ${ }^{3}$, Trine Stub ${ }^{1}$, Anita Salamonsen ${ }^{1}$ and Terje Alræk ${ }^{1}$

\begin{abstract}
Background: The dental filling material amalgam is generally well tolerated. However, a small proportion of dental patients experience health complaints which they attribute to amalgam. The symptom pattern is often similar to patients with medically unexplained physical symptoms (MUPS) and the health complaints may persist after amalgam removal. Among patients with MUPS, the use of complementary and alternative medicine (CAM) seems to be high. The aim of this survey was to describe the prevalence and range of CAM use among people with health complaints attributed to dental amalgam fillings in which the health problems persist after the removal of all amalgam fillings. Specific attention was paid to (1) self-reported effects of CAM, (2) differences in CAM use dependent on self-reported health, and (3) gender differences in self-reported CAM use.
\end{abstract}

Methods: A survey was distributed to all members of The Norwegian dental patient association (NDPA) $(n=999)$, the response rate was $36.4 \%$. The anonymous questionnaire asked for socio-demographic data, health complaints related to former amalgam fillings, subjectively perceived health status, symptoms, and experience with therapeutic interventions, mostly from the spectrum of CAM. Only participants who had all their fillings removed, which was the vast majority, were analysed.

Results: A total of $88.9 \%$ of included respondents had used at least one CAM modality, with a higher proportion of men $(95.7 \%)$ compared to women $(86.2 \%, p=0.015)$. The most frequently used therapies were dietary supplements, vitamins and minerals recommended by a therapist (used by $66.7 \%$ ) followed by self-prescribed dietary supplements, vitamins and minerals (59.0\%), homeopathy (54.0\%), acupuncture (48.8\%) and special diets (47.5\%). Use of CAM was similar for participants reporting normal to good health compared to participants reporting poor health. For all but two CAM modalities, the self-reported treatment effect was better in the group reporting normal to good health compared to the group reporting poor health.

Conclusions: CAM was widely used by participants in our study, a finding similar to findings from studies of MUPS patients. To date, health problems associated with the use of dental amalgam is not an accepted diagnosis in the healthcare system. Consequently, people suffering from such complaints experience a lack of adequate treatment and support within conventional health care, which might have contributed to the high number of CAM users in this study.

\footnotetext{
* Correspondence: agnete.kristoffersen@uit.no

${ }^{1}$ The National Research Center in Complementary and Alternative Medicine, (NAFKAM), Department of Community Medicine, Faculty of Health Sciences, UiT The Arctic University of Norway, Tromsø, Norway

Full list of author information is available at the end of the article
} 


\section{Background}

Amalgam, an alloy of mercury and other metals, has been used as a dental filling material since the $19^{\text {th }}$ century and is well tolerated by most people [1]. However, a proportion of people experience health complaints, which they attribute to amalgam [2-4]. Moreover, for some of these patients the health complains persist even after removal of amalgam fillings. The question whether dental amalgam can cause general health complaints, apart from very rare cases of type- 1 hypersensitivity, remains controversial [1]. Following removal of all dental amalgam fillings, an average of three-fourth of people with amalgam-attributed health complaints report improvement or recovery, while the remainder report no or little improvement or even deterioration [1] (deterioration rates are $0.5 \%-2 \%$ in population-based surveys $[5,6]$ and up to $15 \%$ in selected samples [7-9]).

Health complaints persisting after amalgam removal are often similar to symptom patterns associated with medically unexplained symptoms (MUPS), such as fibromyalgia and myalgic encephalomyelitis (ME). Many of these patients use complementary and alternative medicine (CAM) [10-12]. A study of fibromyalgia patients in the U.S. found that $92.6 \%$ of the participants (mostly women) reported to have used some kind of CAM [10]. CAM is also frequently used by patients with health complaints related to amalgam [9, 13-16]. In recent studies, the most commonly reported CAM modalities for this patient group were dietary supplements/vitamins (58$92 \%)[9,14,15,17]$, homeopathy (17-26 \%) [9, 13, 14], acupuncture (13-28\%) [2, 9, 14, 16] and chiropractic (18-21 \%) $[14,16]$. In Norway the most commonly reported CAM modalities used for amalgam-related health complaints are dietary supplements, acupuncture and homeopathy (65\%, $28 \%$ and $26 \%$ respectively) $[9,17]$. The literature has revealed that the prevalence and associations for use of CAM differs between men and women with regard to several socio demographic variables [18-23] and underline the importance of gender-specific analyses [24].

The dental amalgam safety issue has been debated since the $19^{\text {th }}$ century in the U.S [25], since the 1920s and 1930s in Germany [26, 27] and Denmark [28, 29], and since the 1970 s internationally [30-35] with patient organizations active in a number of European countries, North America, Australia and New Zealand [25]. In Norway the debate started in the early 1980s [36, 37] and in 1990 The Norwegian dental patient association (NDPA, Forbundet Tenner og Helse in Norwegian) was founded. NDPA is a non-profit patient organization working for a non-toxic dentistry. The association also works to ensure that people, who experience themselves as being hurt/injured by dentistry, shall be entitled to rehabilitation and community support. The survey reported here was conducted in close cooperation with
NDPA and is thus in accordance with the emphasis on patient involvement in recent health strategy documents from Norwegian health authorities.

In a representative survey of the adult Norwegian population from 2006, between $5 \%$ and $8 \%$ of the participants expressed the belief that their amalgam fillings had affected their health adversely. Further, a total of $43 \%$ of adults with amalgam fillings had some or all amalgam fillings removed and in $8 \%$ of these participants, the reasons for the removal of the fillings were exclusively due to general health concerns [5]. Moreover, knowledge about the use of CAM among Norwegians with health complaints attributed to amalgam, is limited to a few studies that describe a limited number of CAM modalities $[9,17]$.

This cross-sectional survey is part of a collaborative treatment project for people with suspected adverse effects from dental amalgam and serve as a basis for the development of a treatment program, especially designed for this group of patients. The overall aim of this study was to describe the prevalence and range of CAM use among people with health complaints attributed to amalgam fillings, in which these health complaints persist after the removal of all amalgam fillings. Specific attention was paid to (1) self-reported effects of CAM treatments on health complaints, (2) potential differences in CAM use between participants with self-reported good vs. poor health, and (3) possible gender differences in self-reported CAM use.

Since there is no well-established, general pathophysiological explanation for the experienced symptoms in this group, we will use the term "amalgam-attributed health complaints" throughout the manuscript to denote general symptoms or health complaints for which the people affected or other concerned persons suspect the cause to be amalgam fillings, regardless if such a causal association has been substantiated or not.

\section{Methods}

The survey was distributed to all members of NDPA in December 2011 with a reminder in February 2012. No inquiry about medical diagnoses was made, thus, no information on whether the amalgam-attributed health complaints of the participants could be explained by specific diseases or were medically unexplained (MUPS) was possible. Common to all participants was the attribution of their health complaints to former dental amalgam fillings.

The study participants returned the questionnaires anonymously to The National Research Center in Complementary and Alternative Medicine (NAFKAM) by means of a pre-stamped envelope. The anonymous questionnaire included socio demographic data, conditions related to the amalgam removal, subjectively perceived health status, 
symptoms, and experience with therapeutic interventions, mostly from the spectrum of CAM. Participants with remaining amalgam fillings were not asked to complete the survey and were therefore excluded from the study.

In this study a participant was defined as a CAM user, according to his or her answer to the following question:

If you have removed all your amalgam fillings because of health complaints, which other treatment modalities (forms) have you specifically tried for those health complaints? (Tick $(x)$ for every modality you have tried or not tried. Specify the name of the medication, diets and treatment institutions you have tried.

Dietary supplements, vitamins and minerals recommended by therapist (DSVMT), Dietary supplements, vitamin and minerals self-prescribed (DSVMS), Homeopathy, Acupuncture, Special diet, Reflexology, Massage, Herbs, Healing, Ear Acupuncture, Kinesiology, Magnetic field therapy, Naprapathy, Biopathy, Thought field therapy, Rehabilitation in a CAM institution, Craniosacral therapy, Lightening process.

Participants answering "I have tried" for at least one of the CAM modalities listed above were defined as users. Participants who answered "I have not tried" or had missing values in combination with no statement of effect for all listed CAM modalities were defined as nonusers of CAM. The perceived effect of the treatment was indicated for each treatment as either "good effect", "small/no effect" or "worsening".

The CAM modalities were classified in accordance with the recommendation from The National Center for Complementary and Integrative Health (NCCIH) into the following five categories: 1) alternative medical systems, or complete systems of therapy and practice such as Traditional Chinese Medicine and homeopathy; 2) mind-body interventions, or techniques designed to facilitate the mind's effect on bodily functions and symptoms such as meditation; 3) biologically-based systems, including herbalism; 4) manipulative and body-based methods, such as chiropractic and massage therapy and 5) energy therapies such as healing [2].

Between-group differences were analyzed using chisquare tests for binary data analyzing one variable at the time and one-way ANOVA test for continuous data in SPSS for Windows (version 22.0, SPSS, Inc., Chicago, IL). Significance level was defined as $p<0.05$ without $p$-value adjustment for multiple comparisons.

The Norwegian Data Inspectorate has been notified about the study and the Regional Committee for Medical and Health Research Ethics (REK) has approved the study (REK reference 2011/1281).

\section{Results}

A total of 999 envelopes with questionnaires were sent out, of which 46 were returned unopened to sender. Overall, 953 members of NDPA received the questionnaire and a total of 347 responded (36.4\% response rate) (Fig. 1).

\section{Basic characteristics of the participants}

The majority of the participants were women $(71.6 \%)$ and most participants reported normal to good health (62.4\%). Half of the participants were holding a university degree and mean age was 60 years. The women were slightly older than the men $(p=0.001)$ and men were more often still working. No significant gender differences were found with regard to education nor selfreported health (Table 1).

\section{CAM use and perceived effect of CAM in the total population}

The mean number of different CAM therapy modalities used per participant was 5.7 with a median of 5 in both men and women, ranging from 0 to 15 modalities. The most commonly used CAM modalities were DSVMT (in $66.7 \%$ of participants), DSVMS (59.0\%), homeopathy (54.0\%), acupuncture (48.8\%), reflexology (42.3\%), massage $(40.1 \%)$ and healing (33.6 \%). The perceived effects of dietary supplements, vitamins and minerals (DSVMT/DSVMS) were mostly reported to be good (63.0-74.7 \%). Roughly half of users reported good effect of homeopathy (57.4\%), reflexology (48.6\%) and massage $(41.4 \%)$. By contrast, only one third of users reported good effects of healing (33.8\%) and acupuncture

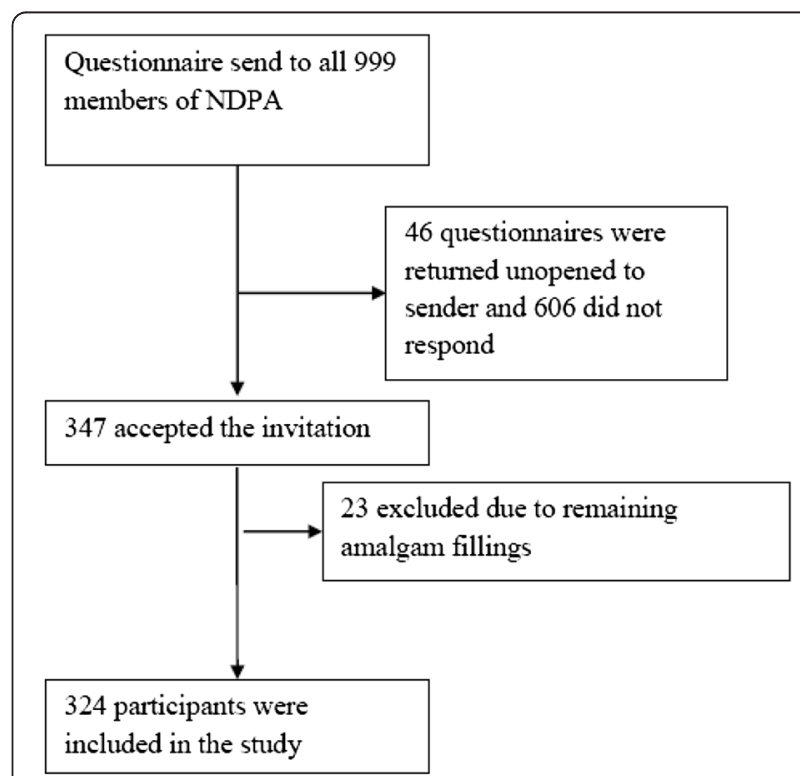

Fig. 1 Flow chart showing the selection of the studied population. NDPA: Norwegian Dental Patients Association 
Table 1 Basic characteristics of the participants

\begin{tabular}{|c|c|c|c|c|}
\hline & Total & Men & Women & $p$-value \\
\hline & $\%(n)$ & $\%(n)$ & $\%(n)$ & \\
\hline \multicolumn{5}{|l|}{ Gender } \\
\hline Women & $71.6(232)$ & & & \\
\hline Men & $28.4(92)$ & & & \\
\hline \multicolumn{5}{|l|}{ Age } \\
\hline Mean & 60.0 & 58.8 (SD 11.12) & 61.3 (SD 10.26) & $0.001^{*}$ \\
\hline \multicolumn{5}{|l|}{ Education } \\
\hline Primary school & $13.4(42)$ & $7.9(7)$ & $15.6(35)$ & \\
\hline $\begin{array}{l}\text { Secondary } \\
\text { school }\end{array}$ & $27.4(86)$ & $32.6(29)$ & $25.3(57)$ & \\
\hline High school & $15.6(49)$ & $13.5(12)$ & $16.4(37)$ & \\
\hline $\begin{array}{l}\text { University, } \\
\text { lower grade }\end{array}$ & $22.0(69)$ & $25.8(23)$ & $20.4(46)$ & \\
\hline $\begin{array}{l}\text { University, } \\
\text { higher grade }\end{array}$ & $27.1(68)$ & $20.2(18)$ & $22.2(50)$ & $0.252^{* *}$ \\
\hline \multicolumn{5}{|l|}{ Self-reported health } \\
\hline Normal to good & $62.4(199)$ & $64.8(59)$ & $61.4(140)$ & \\
\hline Poor & $37.6(32)$ & $35.2(32)$ & $38.6(88)$ & $0.568^{* *}$ \\
\hline \multicolumn{5}{|l|}{ Working } \\
\hline Yes & $59.0(128)$ & $71.0(49)$ & $53.4(79)$ & \\
\hline No & $41.0(89)$ & $29.0(20)$ & $46.6(69)$ & $0.014^{* *}$ \\
\hline
\end{tabular}

*One-way ANOVA test

**Pearson Chi-Square test

(38.8\%). Of the studied population, $12.3 \%(n=40)$ reported worsening of symptoms that they related to their use of one or more CAM modalities. In seven out of 18 treatment modalities worsening of symptoms were reported by $5 \%$ or more. Lightning process and thought field therapy were the only treatment modalities with no worsening of symptoms reported (Table 2).

\section{Gender specific CAM use and perceived effect of CAM}

Overall CAM use was more frequently reported by men (95.7 \%) than women $(86.2 \%)(p=0.015)$. Among men, the most commonly used CAM modalities were DSVMT (72.8 \%) followed by DSVMS (71.7 \%), homeopathy (56.5\%) and special diet (55.4\%). Among women, DSVMT was most commonly used (64.2\%), followed by DSVMS (53.9\%), homeopathy (53.0\%) and acupuncture (48.7\%).

Comparing the use of individual CAM modalities between women and men, women were significantly more likely to use DSVMS (71.7 \% vs. $53.9 \%, p=0.003)$ and less likely to use naprapathy (6.5 \% vs. $15.9 \%, p=0.024)$. No significant gender differences were found in regard to CAM categories, though with a trend towards more frequent use of biological-based systems by men $(p=0.064)$.

No significant gender differences were found with regard to self-reported effect of the received CAM treatment (Table 3).
CAM use and perceived effect of CAM: subgroup analysis according to self-reported health

When men and women were divided into groups of selfreported health, no gender differences were found in the group reporting normal to good health. In the poor health group, on the other hand, the gender differences reported above remained, with the addition of another therapy, magnetic-field therapy, which was significantly more often used among women than men.

There were no significant differences in overall CAM use between the groups reporting normal to good health and poor health. However, the CAM category "alternative medical systems" was more commonly used among participants who reported poor health compared to participants who reported normal to good health $(p=0.032)$. With regard to individual CAM modalities, the poor health group was more likely to use special diets, spiritual healing, biopathy and Lightning Process than the group reporting normal to good health. The self-reported effects of the CAM therapy modalities were reported to be better in the normal to good health group than in the poor health group (Table 3 ).

\section{Discussion}

In this cross-sectional survey of members of NDPA with persistent health complaints attributed to former amalgam fillings, $89 \%$ had used CAM for their health complaints. DSVMT was the most commonly used CAM modality followed by DSVMS, homeopathy, acupuncture and special diet. Similar use was found in participants reporting normal to good health and participants reporting poor health. The self-reported effect of different CAM modalities was highest in the group with normal to good health. More men than women reported use of CAM in this study. Thus, similar to patients with MUPS, patients with amalgam attributed health complaints are frequent users of CAM.

Health care providers often find patients with medically unexplained symptoms difficult to handle, and misunderstandings between health care providers and patients seem to be common [38]. Since adverse effects from dental amalgam is not an accepted diagnosis in the healthcare system, the reasons why people with amalgam attributed health complaints turn to CAM modalities, as reported in our study, may be similar.

Our findings of high use of CAM in general and dietary supplements and vitamins/minerals in particular are in accordance with findings in other studies of patients with amalgam-attributes health complaints [9, 13-15, 17]. This high use might be partly caused by the fact that patient associations and some doctors and therapists recommend vitamins and minerals in conjunction with amalgam removal [39-41]. Our finding of rather frequent use of homeopathy was also reported in another Norwegian 
Table 2 CAM use and perceived effect in the total population $(n=324)$

\begin{tabular}{|c|c|c|c|c|}
\hline & Reported use & Good effect & No effect & Worsening \\
\hline & $\%(n)$ & $\%\left(n^{\mathrm{a}}\right)$ & $\%\left(n^{a}\right)$ & $\%\left(n^{\mathrm{a}}\right)$ \\
\hline Over all CAM use & $88.9(288)$ & & & \\
\hline Alternative medical systems & $68.5(222)$ & & & \\
\hline Homeopathy & $54.0(175)$ & $57.4(81)$ & $39.7(56)$ & $2.8(4)$ \\
\hline Acupuncture & $48.8(158)$ & $38.8(52)$ & $58.2(78)$ & $3.0(4)$ \\
\hline Ear acupuncture & $32.7(106)$ & $38.8(33)$ & $58.8(50)$ & $2.4(2)$ \\
\hline Mind-body interventions & $16.0(52)$ & & & \\
\hline Thought field therapy & $12.0(39)$ & $37.5(12)$ & $62.5(20)$ & $0(0)$ \\
\hline Lightning process & $4.9(16)$ & $46.2(6)$ & $53.8(7)$ & $0(0)$ \\
\hline Biologically-based systems. including herbalism & $84.3(273)$ & & & \\
\hline DSVMT & $66.7(216)$ & $74.7(139)$ & $23.1(43)$ & $2.2(4)$ \\
\hline DSVMS & $59.0(191)$ & $63.0(92)$ & $32.2(47)$ & $4.8(7)$ \\
\hline Special diet & $47.5(154)$ & $74.4(96)$ & $23.3(30)$ & $2.3(3)$ \\
\hline Herbs & $37.7(122)$ & $55.6(50)$ & $38.9(35)$ & $5.6(5)$ \\
\hline Biopathy ${ }^{\mathrm{b}}$ & $13.3(43)$ & $40.6(13)$ & $56.3(18)$ & $3.1(1)$ \\
\hline Manipulative and body-based methods & $61.4(199)$ & & & \\
\hline Reflexology & $42.3(137)$ & $48.6(52)$ & $45.8(49)$ & $5.6(6)$ \\
\hline Massage & $40.1(130)$ & $41.4(41)$ & $43.4(43)$ & $15.2(15)$ \\
\hline Kinesiology & $29.3(95)$ & $43.3(29)$ & $50.7(34)$ & $6.0(4)$ \\
\hline Naprapathy ${ }^{c}$ & $13.3(43)$ & $46.4(13)$ & $46.4(13)$ & $7.1(2)$ \\
\hline Craniosacral therapy & $8.6(28)$ & $42.9(9)$ & $47.6(10)$ & $9.5(2)$ \\
\hline Energy therapies & $41.7(135)$ & & & \\
\hline Healing & $33.6(109)$ & $33.8(26)$ & $63.6(49)$ & $2.6(6)$ \\
\hline Magnetic field therapy & $19.1(62)$ & $29.5(13)$ & $61.4(27)$ & $9.1(4)$ \\
\hline Rehabilitation in a CAM institution & $9.3(30)$ & $80.0(20)$ & $16.0(4)$ & $4.0(1)$ \\
\hline
\end{tabular}

study of patients with amalgam-attributed health complaints [9]. The possible lack of adequate conventional treatment available for these health problems might be the reason for the high number of CAM users in this study. Also the fact that the period for CAM use in this study was "since onset of the health complaints" (instead of commonly "in the past year" or similar), might have contributed to the high frequency of CAM use.

The higher use of CAM among men than women in our study is not in accordance with findings in previous studies of other patient groups [18-22]. The reason for this might be the highly selected group of male participants due to membership in a patient association and removal of their amalgam filling at their own expense. The fact that more men than women were still working might have given more of the men the financially abilities to finance CAM use, since CAM is mainly paid out-of-pocket in Norway. The lower use of CAM among men than women in most other studies is often attributed to a presumption that men's health care needs are better met within conventional health care [42], while we here see CAM use in a population that do not find their health care needs met within conventional health care [10]. Educational level and self-reported health were similar in men and women and these factors can therefore not explain the differences in CAM use.

The better self-reported effect of the CAM treatment among the participants with normal to good health compared to those with poor health is an interesting finding and not easy to explain. Generally, since this is a crosssectional survey, it is impossible to make causal interpretations. Possibly, differential effects of CAM therapy could lead to different degrees of health improvement in participants with similar health status before therapy.

Worsening of symptoms following CAM treatment was reported by $12.3 \%$ of the participants in our study. For homeopathy, worsening was reported by $2.8 \%$ of users, which is much lower than in another Norwegian 
Table 3 Gender- and health specific use and effect of CAM

\begin{tabular}{|c|c|c|c|c|c|c|c|c|c|c|c|c|}
\hline & \multirow{2}{*}{$\begin{array}{l}\text { Use of CAM } \\
\text { Men }\end{array}$} & \multirow[b]{2}{*}{ Women } & \multirow{3}{*}{$p$-value } & \multicolumn{2}{|c|}{ Good effect of CAM } & \multirow{3}{*}{$p$-value } & \multirow{2}{*}{$\begin{array}{l}\text { Use of CAM } \\
\text { Normal to } \\
\text { good health }\end{array}$} & \multirow[b]{2}{*}{ Poor health } & \multirow{3}{*}{$p$-value } & \multicolumn{2}{|c|}{ Good effect of CAM } & \multirow{3}{*}{$p$-value } \\
\hline & & & & Men & Women & & & & & $\begin{array}{l}\text { Normal to } \\
\text { good health }\end{array}$ & Poor health & \\
\hline & $\%(n)$ & $\%(n)$ & & $\%(n)$ & $\%(n)$ & & $\%(n)$ & $\%(n)$ & & $\%(n)$ & $\%(n)$ & \\
\hline Overall CAM use & $95.7(88)$ & $86.2(200)$ & 0.015 & & & & $89.9(179)$ & $88.3(106)$ & $0.650^{*}$ & & & \\
\hline Alternative medical systems & $68.5(63)$ & $68.5(159)$ & 0.992 & & & & $64.3(128)$ & $75.8(91)$ & $0.032^{*}$ & & & \\
\hline Homeopathy & $56.5(52)$ & $53.0(123)$ & 0.568 & $52.3(23)$ & $59.8(58)$ & $0.403^{*}$ & $50.3(100)$ & $60.0(72)$ & $0.091^{*}$ & $68.4(54)$ & $42.4(25)$ & $0.002^{*}$ \\
\hline Acupuncture & $48.9(45)$ & $48.7(113)$ & 0.973 & $33.3(13)$ & $41.1(39)$ & $0.405^{*}$ & $46.2(92)$ & $54.2(65)$ & $0.170^{*}$ & $49.3(37)$ & $25.9(15)$ & $0.006^{*}$ \\
\hline Ear acupuncture & $31.5(29)$ & $33.2(77)$ & 0.851 & $32.0(8)$ & $41.7(25)$ & $0.405^{*}$ & $34.2(68)$ & $30.8(37)$ & $0.539^{*}$ & $43.4(23)$ & $29.0(9)$ & $0.191^{*}$ \\
\hline Mind-body interventions & $14.1(13)$ & $16.8(39)$ & 0.553 & & & & $15.1(30)$ & $18.3(22)$ & $0.445^{*}$ & & & \\
\hline Thoughtfield therapy & $10.9(10)$ & $12.5(29)$ & 0.684 & $42.9(3)$ & $36.0(9)$ & $0.740^{*}$ & $12.6(25)$ & $11.7(14)$ & $0.813^{*}$ & $47.6(10)$ & $18.2(2)$ & $0.139^{* *}$ \\
\hline Lightening process & $4.3(4)$ & $5.2(12)$ & 0.757 & $33.3(1)$ & $50.0(5)$ & $1.000^{* *}$ & $2.5(5)$ & $9.2(11)$ & $0.008^{*}$ & $60.0(3)$ & $37.5(3)$ & $0.592^{* *}$ \\
\hline Biologically-based systems. including herbalism & $90.2(83)$ & $81.9(190)$ & 0.064 & & & & $86.9(173)$ & $80.8(97)$ & $0.143^{*}$ & & & \\
\hline DSVMT & $72.8(67)$ & $64.2(149)$ & 0.139 & $74.2(46)$ & $75.0(93)$ & $0.905^{*}$ & $68.8(137)$ & $64.2(77)$ & $0.389^{*}$ & $80.7(96)$ & $63.6(42)$ & $0.011^{*}$ \\
\hline DSVMS & $71.7(66)$ & $53.9(125)$ & 0.003 & $66.1(37)$ & $61.1(55)$ & $0.546^{*}$ & $60.3(120)$ & $58.3(70)$ & $0.729^{*}$ & $72.2(70)$ & $43.8(21)$ & $0.001^{*}$ \\
\hline Special diet & $55.4(51)$ & $44.4(103)$ & 0.073 & $76.1(35)$ & $73.5(61)$ & $0.746^{*}$ & $42.7(85)$ & $56.7(68)$ & $0.016^{*}$ & $79.5(58)$ & $67.3(37)$ & $0.119^{*}$ \\
\hline Herbs & $35.9(33)$ & $38.4(89)$ & 0.676 & $63.0(17)$ & $52.4(33)$ & $0.355^{*}$ & $35.7(71)$ & $41.7(50)$ & $0.286^{*}$ & $58.8(30)$ & $50.0(19)$ & $0.408^{*}$ \\
\hline Biopathy & $10.9(10)$ & $14.2(33)$ & 0.422 & $50.0(5)$ & $36.4(8)$ & $0.699^{* *}$ & $10.1(20)$ & $19.2(23)$ & $0.021^{*}$ & $35.7(5)$ & $44.4(8)$ & $0.618^{*}$ \\
\hline Manipulative and body-based methods & $60.9(56)$ & $61.6(143)$ & 0.898 & & & & $59.3(118)$ & $65.5(79)$ & $0.245^{*}$ & & & \\
\hline Reflexology & $41.3(38)$ & $42.7(99)$ & 0.822 & $41.9(13)$ & $51.3(39)$ & $0.378^{*}$ & $40.2(80)$ & $45.8(55)$ & $0.324^{*}$ & $51.6(32)$ & $43.2(19)$ & $0.392^{*}$ \\
\hline Massage & $33.7(31)$ & $42.7(99)$ & 0.137 & $58.3(14)$ & $36.0(27)$ & $0.053^{*}$ & $38.7(77)$ & $43.3(52)$ & $0.413^{*}$ & $46.3(25)$ & $36.4(16)$ & $0.321^{*}$ \\
\hline Kinesiology & $29.3(27)$ & $29.3(68)$ & 0.995 & $40.0(8)$ & $44.7(21)$ & $0.723^{*}$ & $27.1((54)$ & $33.3(40)$ & $0.240^{*}$ & $40.6(13)$ & $44.1(15)$ & $0.774^{*}$ \\
\hline Naprapathy & $6.5(6)$ & $15.9(37)$ & 0.024 & $75.0(3)$ & $41.7(10)$ & $0.311^{* *}$ & $12.1(24)$ & $14.2(17)$ & $0.586^{*}$ & $50.0(8)$ & $40.0(4)$ & $0.619^{* *}$ \\
\hline Craniosacral therapy & $5.4(5)$ & $9.9(23)$ & 0.196 & $80.0(4)$ & $31.3(5)$ & $0.119^{* *}$ & $9.0(18)$ & $8.3(10)$ & $0.828^{*}$ & $75.0(9)$ & $0.0(0)$ & $0.001^{* *}$ \\
\hline Energy therapies & $40.2(37)$ & $42.2(98)$ & 0.739 & & & & $40.7(81)$ & $44.2(53)$ & $0.544^{*}$ & & & \\
\hline Healing & $35.9(33)$ & $32.8(76)$ & 0.593 & $37.5(9)$ & $32.1(17)$ & $0.641^{* *}$ & $29.1(58)$ & $41.7(50)$ & $0.022^{*}$ & $47.2(17)$ & $20.0(8)$ & $0.012^{*}$ \\
\hline Magneticfield therapy & $14.1(13)$ & $21.1(49)$ & 0.149 & $36.4(4)$ & $27.3(9)$ & $0.706^{* *}$ & $22.6(45)$ & $14.2(17)$ & $0.065^{*}$ & $38.7(12)$ & $7.7(1)$ & $0.068^{* *}$ \\
\hline Rehabilitation in a CAM institution & $7.6(7)$ & $9.9(23)$ & 0.519 & $66.7(4)$ & $84.2(16)$ & $0.562^{* *}$ & $10.6(21)$ & $7.5(9)$ & $0.366^{*}$ & $94.4(17)$ & $42.9(3)$ & $0.012^{* *}$ \\
\hline
\end{tabular}

Pearson Chi-Square test

${ }^{*}$ Fisher's Exact test 
study where $26 \%$ reported worsening after homeopathic treatment regardless of health complains [43]. The deterioration rate following CAM therapy for amalgamattributed health complaints in this study (12.3\%) was similar to deterioration rates in three studies of amalgam removal for the same indication, also in highly selected patient groups $(9.5 \%$ of members of a Swedish dental patient association [7]; $14.7 \%$ and $13 \%$ of patients referred to dental material adverse reaction units in Sweden [29] and Norway [30], respectively) [7-9]. Possibly, deterioration following CAM treatment in this study could be related to characteristics of the selected patient group and not just to features of the CAM interventions.

\section{Limitations}

The main limitation of this study is the highly selected target group: In order to identify and reach patients with persistent health complaints attributed to former amalgam fillings, subjects were recruited from a specific patient association and may therefore not be representative for the total patient group. A German study shows that members of fibromyalgia self-help groups use significantly more CAM than patients not affiliated with selfhelp groups [11] while in a Norwegian study of people with amalgam-attributed health complaints, those who had removed all their amalgam fillings were significantly more likely to use homeopathy and natural therapy than those who still had amalgam fillings [9]. The survey had a modest response rate $(36.4 \%)$ which may influence the generalizability of the findings. This survey did not contain diagnoses of the health complaints; therefore, the prevalence of related conditions such as MUPS cannot be assessed. Since the CAM use was not limited in time, but related to the amalgam health complaints, regardless of when they started, the recall period concerning CAM use might have been long and resulted in inaccuracies with regard to the reported use of CAM therapies. Also, the reported subgroup differences with regard to CAM use and self-reported CAM effects should be treated with caution, because of multiple hypothesis testing and due to low sample sizes in some subgroups.

\section{Interpretation}

This is the first survey of CAM use among people with amalgam-attributed health complaints in Norway addressing a broad range of CAM modalities. To our knowledge, it is the first study of CAM use worldwide to focus on the subgroup of people with amalgam-attributed health complaints, in which the health complaints persist following complete amalgam removal, and is therefore a door opener to the field. The results from this study were used for the development of an Integrated Medical Care
Rehabilitation program for this patient group, in which CAM is given as a part of the program.

\section{Conclusion}

Findings from this study suggest that CAM was widely used by people with health complaints attributed to dental amalgam fillings, and who had removed all amalgam fillings, and were member of a patient organization, NDPA. The reasons for the considerably high use of various CAM modalities may be related to the experienced lack of support and treatment offers within the conventional health care system.

\begin{abstract}
Abbreviations
MUPS: Medically unexplained physical symptoms; ME: Myalgic encephalomyelitis; CAM: Complementary and Alternative Medicine; NAFKAM: National Research Center in Complementary and Alternative Medicine; OTC: Over the counter; NDPA: Norwegian Dental Patients Association (Forbundet tenner og helse in Norwegian); NCCIH: National Center for Complementary and Integrative Health; DSVMT: Dietary supplements, vitamins and minerals recommended by therapist; DSVMS: Dietary supplements, vitamin and minerals self-prescribed; REK: Regional Committee for Medical and Health Research Ethics.
\end{abstract}

\section{Competing interests}

The authors declare that they have no competing interests.

\section{Authors' contributions}

TA conceived the study, TA; HJH and LB compiled the questionnaires, AEK and FM performed the initial and final analyses. All authors helped draft the manuscript and reviewed subsequent versions; and all authors read and approved the final manuscript.

\section{Acknowledgements}

We acknowledge the leader and the administration of NDPA with posting the questionnaires to the members of NDPA. Subsequently we are grateful to the members of NDPA who filled in and returned the questionnaires. The study was funded through a grant from the Norwegian Directorate of Health. Special thanks to Liljan Smith Aandahl, retired Senior Advisor at the Norwegian Directorate of Health, who was instrumental in setting up the project for people with suspected adverse effects from dental amalgam, which this study is part of

\section{Author details}

The National Research Center in Complementary and Alternative Medicine, (NAFKAM), Department of Community Medicine, Faculty of Health Sciences, UiT The Arctic University of Norway, Tromsø, Norway. ${ }^{2}$ Institute for Applied Epistemology and Medical Methodology at the University of Witten-Herdecke, Freiburg, Germany. ${ }^{3}$ Dental Biomaterials Adverse Reaction Unit, Uni Research Health, Bergen, Norway.

Received: 26 August 2015 Accepted: 12 January 2016 Published online: 22 January 2016

References

1. Helsedirektoratet. Nasjonale faglige retningslinjer for utredning og behandling ved mistanke om bivirkninger fra odontologiske biomaterialer [National guidance for assessment and treatment for suspected side effects from dental biomaterials]: Helsedirektoratet, Avdeling omsorg og tannhelse; 2008.

2. Östlin L. Amalgamutbyte - en väg mot bättre hälsa? [Amalgam Replacement - a path towards better health?]. Stockholms Län: 1991.

3. Lygre GB, Helland V, Gjerdet NR, Bjørkman L. Pasienter med helseplager relatert til tannfyllinger. Tidsskr Nor Laegeforen. 2007;11(127):1524-8.

4. Sjursen TT, Binder PE, Lygre GB, Helland V, Dalen K, Björkman L. Patients experiences of changes in health complaints before, during, and after removal of dental amalgam. 2015. 2015;10. 
5. Norheim AJ, Ramstad S. Opplevde sammenhenger mellom amalgam og helse i den norske befolkning [Perceived associations between amalgam and health in the Norwegian population]. Nasjonalt Forskningssenter innen komplementær og alternativ medisin - NAFKAM, Universitetet i Tromsø: $2006829267201 X$

6. Allmänhetens inställning till och besvär av tandfyllningar med amalgam [Public attitudes to and inconvenience of dental fillings with amalgam]. Stockholm: 1993.

7. Hanson M. Förändringar i hälsotillståndet efter utbyte av giftiga tandfyllningsmaterial. En epidemiologisk studie av 519 personer med misstänkt kvicksilverförgiftning [Changes in health status by replacement of toxic dental filling materials. An epidemiological study of 519 people with suspected mercury poisoning]. Tandvårdsskadeförbundets medlemsbulletin. 1986;1(1):1-30.

8. Lindh U, Hudecek R, Danersund A, Eriksson S, Lindvall A. Removal of dental amalgam and other metal alloys supported by antioxidant therapy alleviates symptoms and improves quality of life in patients with amalgam-associated ill health. Neuro Endocrinol Lett. 2002;23(5-6):459-82.

9. Tannmaterialer og helse: Erfaringer fra klinisk utredning av pasienter med mistanke om bivirkninger fra tannmaterialer [Dental Materials and health: Experiences from clinical evaluation of patients with suspected adverse effects from dental materials] Bergen: Bivirkningsgruppen for odontologiske biomaterialer, 2006.

10. Wall GC, Krypel LL, Miller MJ, Rees DM. A pilot study of complementary and alternative medicine use in patients with fibromyalgia syndrome. Pharm Pract (Granada). 2007:5(4):185-90.

11. Jung E, Erbsloh-Moller B, Gesmann M, Kuhn-Becker H, Petermann F, Langhorst J, et al. Sind Mitglieder von Fibromyalgiesyndrom-Selbsthilfegruppen "anders"? [Are members of fibromyalgia syndrome self-help groups "different"? Demographic and clinical characteristics of members and non-members of fibromyalgia syndrome self-help groups]. Z Rheumatol. 2013;72(5):474-81.

12. Jones JF, Maloney EM, Boneva RS, Jones AB, Reeves WC. Complementary and alternative medical therapy utilization by people with chronic fatiguing illnesses in the United States. BMC Complement Altern Med. 2007;7:12.

13. Mörnstad H, Teivens A, Wänman A. Sjukdomsbild och attityder till amalgam [lllness and attitudes to dental amalgam]. Tandlakartidningen. 1994;83:196-204.

14. Lindberg A. Are they really sick? Stockholm: A report on the ElectroSensitive and the Dental Materials Injured in Sweeden; 2008.

15. Georgellis A, Savlin P, Hillert L, Thunberg E, Lundqvist M, Björkman L. Amalgam och hälsa: En uppföljningsstudie av patienter från Stockholms län som remitterades till tidigare Amalgamenheten vid Huddinge sjukhus [Amalgam and health: A follow-up study of patients from Stockholm County who was referred to earlier Amalgam unit at Huddinge Hospital]. 2002.

16. Olsson G, Lindh U. Veränderung des allgemeinen Gesundheitszustand nach Amalgamentfernung - eine zähnjährige Strudie [Changes in general health after amalgam replacement - a 10 years study]. GZM Ganzheitl Zahnmed. 1997;2:22-8

17. Sjursen $\Pi$, Lygre GB, Dalen $K$, Helland V, Laegreid T, Svahn J, et al. Changes in health complaints after removal of amalgam fillings. J Oral Rehabil. 2011;38(11):835-48

18. Hanssen B, Grimsgaard S, Launso L, Fonnebo V, Falkenberg T, Rasmussen N. Use of complementary and alternative medicine in the Scandinavian countries. Scand J Prim Health Care. 2005;23(1):57-62.

19. Barnes P, Bloom B, Nahin R. Complementary and alternative medicine use among adults and children: United States, 2007. Natl Health Stat Report. 2008;12:1-23.

20. Quandt S, Verhoef M, Arcury T, Lewith G, Steinsbekk A, Kristoffersen A, et al. Development of an international questionnaire to measure use of complementary and alternative medicine (I-CAM-Q). J Altern Complement Med. 2009;15(4):331-9.

21. Bishop F, Lewith G. Who uses CAM? A narrative review of demographic characteristics and health factors associated with CAM use. Evid Based Complement Alternat Med. 2010;7(1):11-28.

22. Hansen AH, Kristoffersen AE, Lian OS, Hanlvorsen PA. Continuity of GP care is associated with low use of complementary and alternative medical providers: A populationbased cross-sectional survey. BMC Health Serv Res. 2014;14:629.

23. Kristoffersen A, Stub T, Salamonsen A, Musial F, Hamberg K. Gender differences in prevalence and associations for use of CAM in a large population study. BMC Complement Altern Med. 2014;14(1):463.
24. Kristoffersen AE, Norheim AJ, Fonnebo VM. Complementary and alternative medicine use among Norwegian cancer survivors: gender-specific prevalence and associations for use. Evid Based Complement Alternat Med. 2013:2013:318781.

25. Björklund G. Bruk av tannrestaureringsmaterialer i et historisk perspektiv [The use of dental materials in a historical perspective]. Oslo: 1998 Contract No.: IK-2652.

26. Fleischmann P. Zur Frage der Gefährlichkeit kleinster Quecksilbermengen. [On the hazards of minute amounts of mercury]. Dtsch Med Wschr. 1928;8:304-7.

27. Stock A. Die Gefährlichkeit des Quecksilberdampfes. [The hazards of mercury vapor]. Z Angew Chemie. 1926;39:461-6.

28. Steffensen K. Om kronisk kvikksølvforgiftning foraarsaget af tandplomber. [Chronic mercury poisoning from dental fillings]. Ugeskr Laeger. 1934;96:855-8.

29. Schmidt-Piseldeck K. Om "nervøse" fænomener og amalgamplomber. ["Nervous" phenomena and amalgam fillings]. Tandlaegebladet. 1936;40:598-603.

30. Godfrey M. Dental amalgam - a potentially toxic source of mercury? N Z Sci Rev. 1992:42:52-6.

31. Amalgam - Pro und Contra. Gutachten - Referates - Statements - Diskussion. Köln: 1992.

32. Status quo and perspectives of amalgam and other dental materials: international symposium proceedings. Stuttgart, New York: 1995.

33. Striden om amalgamet. Forskarnas debatt om kvicksilvret i tandvården [The battle of the amalgam. The researchers' debate on mercury in dentistry]. Stockholm: Forskningsrådsnämnden, 1989 Contract No.: Källa/33.

34. Huggins HA. Medical implications of dental mercury: a review. Explore (NY). 2007:3(2):110-7.

35. Mutter J. Is dental amalgam safe for humans? The opinion of the scientific committee of the European Commission. J Occup Med Toxicol. 2011;6(1):2.

36. Eriksen A. Den offentlige debatten i Norge om amalgam og andre tannfyllingsmaterialer. Bruk av tannrestaureringsmaterialer i Norge. Oslo: Statens Helsetilsyn; 1998.

37. Hamre HJ. Amalgam og sykdom (Amalgam and IIness). Vidarforlaget: Oslo; 1993.

38. Salmon P. Conflict, collusion or collaboration in consultations about medically unexplained symptoms; the need for a curriculum of medical explanation. Patient Educ Couns. 2007;267(3):246-54.

39. Crinnion WJ. Environmental medicine, part three: long-term effects of chronic low-dose mercury exposure. Altern Med Rev. 2000;5(3):209-23.

40. Muran PJ. Mercury elimination with oral DMPS, DMSA, vitamin C, and glutathione: an observational clinical review. Altern Ther Health Med. 2006;12(3):70-5.

41. Broden $\mathrm{G}$, Grönquist $\mathrm{S}$, Hanson M, Molius M. ABC for amalgamskadde $[A B C$ for amalgam injured] 2006. Available from: http://www.tenneroghelse.no/ default.asp? page $=73 \&$ article $=119$.

42. Hamberg K. Gender bias in medicine. Womens Health (Lond Engl). 2008:4(3):237-43.

43. Stub T, Musial F, Kristoffersen A, Alræk T, Steinsbekk A. Risk in Homeopathy: Classification of Adverse Effects and Homeopathic Aggravations-A Cross Sectional Study Among Norwegian Homeopath Patients. Complement Ther Med. 2015:23(4):535-43.

\section{Submit your next manuscript to BioMed Central and we will help you at every step:}

- We accept pre-submission inquiries

- Our selector tool helps you to find the most relevant journal

- We provide round the clock customer support

- Convenient online submission

- Thorough peer review

- Inclusion in PubMed and all major indexing services

- Maximum visibility for your research

Submit your manuscript at www.biomedcentral.com/submit 